\title{
Two new species of Herbrossus (Ephemeroptera: Baetidae) from Madagascar with the first generic description of the adults ${ }^{1}$
}

\author{
J.-L. Gattolliat ${ }^{2}$ \\ M. Sartori ${ }^{3}$
}

Keywords : Ephemeroptera, Baetidae, Herbrossus, new species, Madagascar, carnivorous genus.

Two new species of Herbrossus (Ephemeroptera: Baetidae) are described at the larval stage and for the first time the imagoes of this genus are also described. New information on larval and imaginal stages of the type species H. edmundsorum is presented. Affinities and ecology are discussed.

Deux nouvelles espèces de Herbrossus (Ephemeroptera : Baetidae) de Madagascar et première description générique des adultes

Mots clés : Ephemeroptera, Baetidae, Herbrossus, nouvelles espèces, Madagascar, genre carnivore.

Deux nouvelles espèces d'Herbrossus sont décrites à partir des larves; pour la première fois les imagos de ce genre sont aussi décrits. Des compléments d'information sur l'espèce-type $H$. edmundsorum sont apportés, avec notamment la description de l'imago femelle.

\section{Introduction}

The genus Herbrossus was erected by McCafferty and Lugo-Ortiz to accommodate the new species $H$. edmundsorum. The labrum with narrowly U-shaped anteromedial emargination allows to distinguish it from other genera belonging to the Centroptiloides complex such as Barnumus, Nesoptiloides, Centroptiloides and Edmulmeatus (Lugo-Ortiz \& McCafferty 1998).

During extensive field work led by the team LRSAE (CNRE-ORSTOM) on the Malagasy mayfly fauna, numerous specimens belonging to the genus Herbrossus were caught in different localities throughout Madagascar. This material allows us to describe one new species at the larval stage and another one at the larval

1. Aquatic biodiversity of Madagascar 28.'

2. ORSTOM, LRSAE (Lab. Rech. sur les Systèmes Aquatiques et leur Environnement), BP 434, 101 Antananarivo, Madagascar

Present address: Museum of Zoology, P.O. Box 448, CH-1000 Lausanne 17, Switzerland.

3. Museum of Zoology, P.O. Box 448, CH-1000 Lausanne 17, Switzerland. and the imaginal stages. Moreover, complementary diagnostic features for $H$. edmundsorum are brought to the fore, and the female imago of this species is described for the first time.

The holotypes and part of the paratypes are housed in the Museum of Zoology, Lausanne, Switzerland. Other paratypes are deposited in the Museum National d'Histoire Naturelle, Paris and the Purdue Entomological Research Collection, West Lafayette, Indiana USA.

\section{Herbrossus elouardi Gattolliat \& Sartori sp. $n$.}

\section{Larva}

Maximal length (full grown specimen): Body 12.5 $\mathrm{mm}$. Cerci $11 \mathrm{~mm}$. Terminal filament $4 \mathrm{~mm}$.

Head. Coloration brown with light brown vermiform markings on vertex and frons. Antennae pale yellowish brown, about 3.0 times width of the head capsule; scapus about as long as wide; pedicellus subcylindrical, longer than wide, distal margin U-shaped. Eyes black; ocelli grey. 
Labrum (Fig. 1) with a broad U-shaped anteromedial emargination, dorsally covered with small setae, longer in the distal part; margin laterally and apically with long feathered setae; ventrally with a row of very small setae subparallel to the lateral margin. Hypopharynx as in figure 2; lingua covered with thin setae but without bristle tuft at the apex.

Right mandible (Fig. 3) with a slighty convex angulation on the extern margin; incisors fused to a group of 7 sharp teeth; prostheca quite reduced; 2 distinct tufts of setae between prostheca and mola; patch of small teeth at the base of the mola; tuft of long setae at the apex of the mola; basal half with short thin setae dorsally.

Left mandible (Fig. 4) with a slighty convex angulation on the extern margin; incisors fused to a group of 6 sharp teeth; prostheca well-developed, with 4 or 5 teeth together with a comb-shaped structure at the apex; tuft of setae between prostheca and mola reduced but present; mola surmounted by a stout triangular appendice; mola formed with numerous small teeth; tuft of long setae at the apex of the mola; basal half with short thin setae dorsally.

Maxillae (Fig. 5) with 4 teeth, row of medium single setae ending with a tuft of setae twice as long as the other; in the middle of the range, 2 pectinated spine-like setae; a row of 5 to 6 setae at the basis of the galea; 1 single setae perpendicularly to the margin of the galea; palp 2-segmented subegal to the galealacinia, first segment longer than the second; apex of the second with numerous thin setae, almost no seta on the first segment.

Labium (Fig. 6) with glossae shorter than paraglossae; inner margin of the glossae with stout setae apically, the 3 most apical pectinated, distal half of the outer margin with stout setae, few setae randomly distributed on the ventral side; paraglossae stout, apically rounded, with three rows of simple pectinated setae and 2 or 3 independent simple setae. Labial palp 3-segmented; first segment stout, as long as the second and third combined, almost entirely covered with micropores; second segment moderately produced apicomedially, row of 7 to 9 setae near the outer margin, inner margin covered with thin setae, rarer on the outer margin; third segment subconical, covered with setae.

Thorax. Coloration light brown with medium to dark brown markings.

Forewing pad yellow with inner margin dark brown, major veins well-marked with dark brown lines; hindwing pad present.
Forelegs (Fig. 11) with coxa covered with numerous short stout setae.

Femora with dorsally a double row of long setae, ending with a patch of stout setae; sparse stout setae subparallel to the margin; numerous apically blunt setae on the ventral margin.

Tibiae with dorsally a row of long setae; a row of stout, apically pointed setae becoming longer toward the apex; posterior face almost entirely covered with stout and pointed setae.

Tarsi with a row of thin and long setae, dorsally, becoming scarce at the apex; ventrally, with a row of stout, apically pointed setae becoming longer toward the apex; posterior face with several smaller pointed setae; a tuft of setae at the apex dorsally and ventrally; tarsal claws (Fig. 12) stout with 2 unequal rows of 3 to 4 and 4 to 6 teeth, subapical pair of long, thin, simple setae.

Second and third legs similar to foreleg, but with the setae on the ventral margin less developed.

Abdomen. Coloration yellow to dark brown. Terga 1 to 3 middle to dark brown without clearly distinct marking; terga 4 yellow with a dark brown double elongated marking medio-proximally; terga 5 with the same brown marking as on 4 but middle to dark brown coloration apically; terga 6 and 7 almost completely dark brown; terga 8, 9 and 10 yellow with small rounded markings medio-proximally. At younger stages, the abdomen is less contrasted, sometimes even uniformly middle brown.

Terga (Fig. 8) with abundant scale bases; posterior marginal spines irregular, triangular, longer than wide; thin setae as long as the spines, randomly arranged along the posterior margin and scarce insertion trace of setae between the scale bases; marks of muscular attachments well-developed.

Sterna yellow, without scale base except sublaterally; few short setae randomly distributed; marks of muscular attachments well-developed.

Gills on abdominal segments 1 to 7, well-tracheated, serrated at the apex; gill 1 smaller than the others, shape as in figure 9; Gills 2 to 7 identical in shape (Fig. 10), except 6 and especially 7 smaller.

Paraproct (Fig. 7) with about 25 irregular and blunt marginal spines; surface covered with micropores and scarce scale bases; few thin setae randomly distributed near the margin; postero-lateral extension with numerous small spines along the margin; less than 10 scale bases nearby the margin. 
(3)

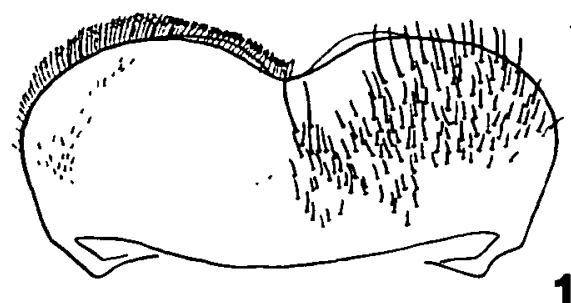

1
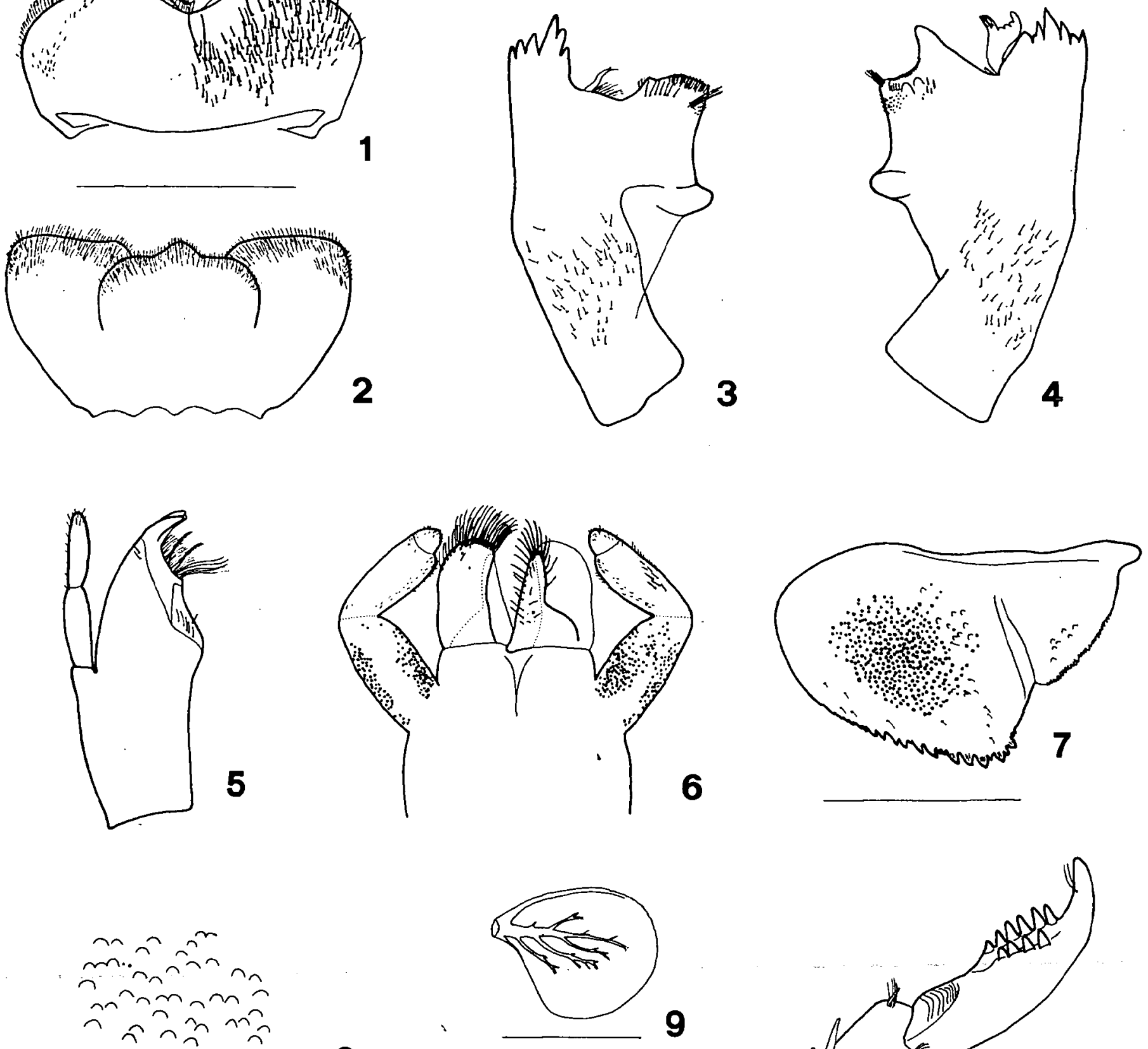

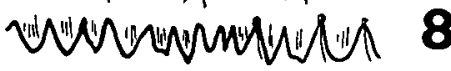

9
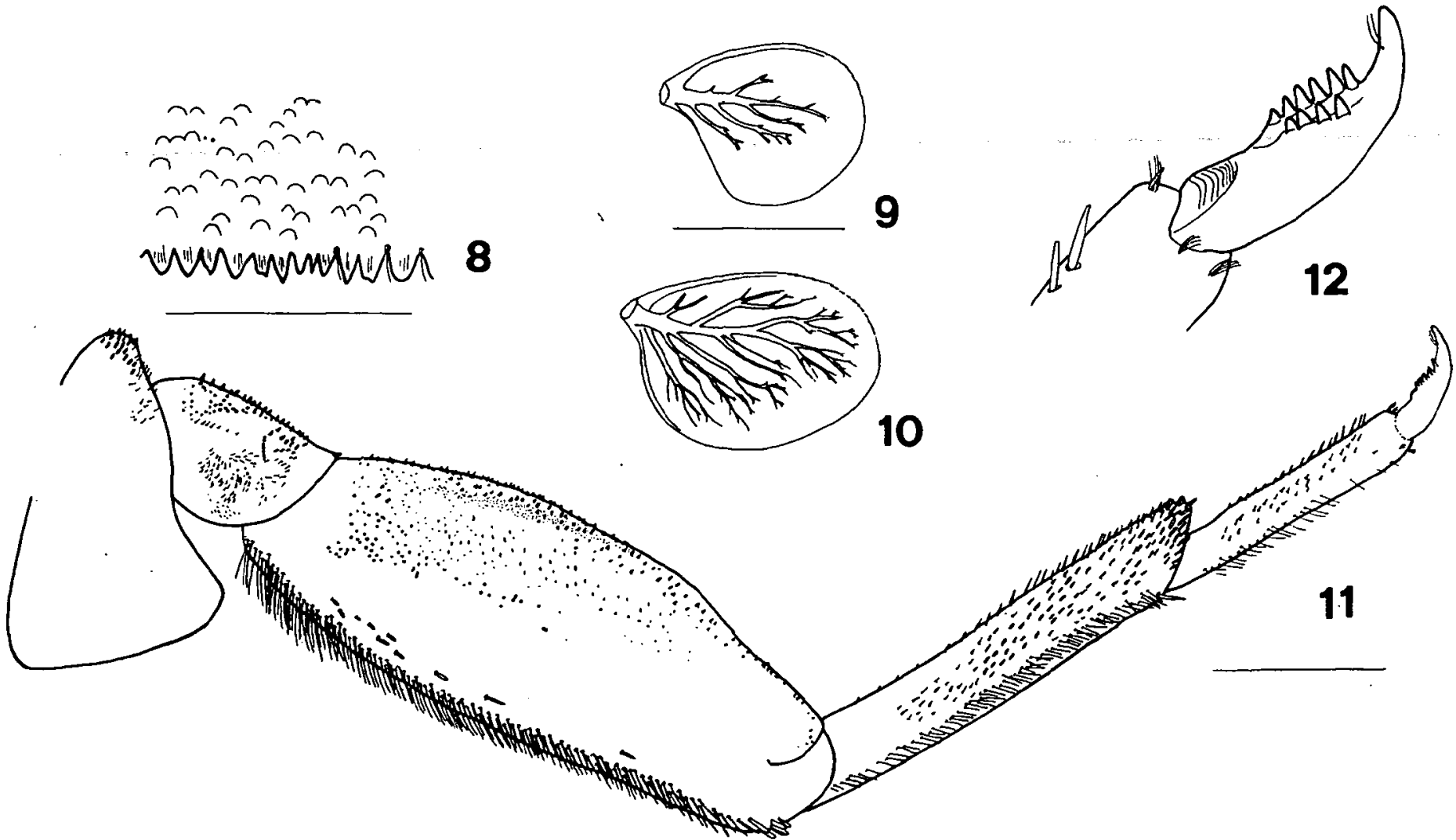

Figs 1 to 12 . Larval structures of $H$. elouardi $: 1:$ labrum. $2:$ hypopharynx. $3:$ right mandible. $4:$ left mandible. $5:$ right maxilla. $6:$ labium (left : ventral; right : dorsal). $7:$ paraproct. $8:$ detail of tergum. $9:$ first gill. $10:$ third gill. $11:$ left foreleg. $12:$ tarsal claw. Scale : $0.5 \mathrm{~mm}$, except fig. $8(0.125 \mathrm{~mm})$, figs. 7,9 and $10(0.25 \mathrm{~mm})$. Same scale for figures 1-6.

Figs 1 à 12. Structures larvaires de $H$. elouardi $: 1:$ labre. $2:$ hypopharynx. $3:$ mandibule droite. $4:$ mandible gauche. $5:$ maxille droite. $6:$ labium (gauche : ventral; droite : dorsal). $7:$ paraprocte. $8:$ détail du tergite. $9:$ première branchie. $10:$ troisième branchie. $11:$ patte antérieure gauche. 12 : griffe tarsale.

Echelle : $0.5 \mathrm{~mm}$, sauf fig. $8(0.125 \mathrm{~mm})$, figs. 7,9 et $10(0.25 \mathrm{~mm})$. Mêmes échelles pour les figures 1 à 6 . 
Table 1. Main distinctive structural characters of the three species of Herbrossus.

Tableau 1. Principaux caractères structuraux distinguant les trois espèces d'Herbrossus.

\begin{tabular}{|c|c|c|c|}
\hline Characters & H. edmundsorum & H. elouardi & H. christinae \\
\hline $\begin{array}{l}\text { Larval length } \\
\text { max. (mm) }\end{array}$ & 10.0 & 12.5 & 10.7 \\
\hline $\begin{array}{l}\text { Mola of the } \\
\text { mandibles }\end{array}$ & normal & normal & reduced \\
\hline $\begin{array}{l}\text { Right mandible } \\
\text { angulation on } \\
\text { the extern } \\
\text { margin }\end{array}$ & $\begin{array}{l}\text { straight to slighty } \\
\text { convex }\end{array}$ & slighty convex & $\begin{array}{l}\text { conspicuous } \\
\text { convex }\end{array}$ \\
\hline $\begin{array}{l}\text { Setae between } \\
\text { prostheca and } \\
\text { mola (right } \\
\text { mandible) }\end{array}$ & very reduced & very reduced & absent \\
\hline $\begin{array}{l}\text { Apex of the } \\
\text { lingua of the } \\
\text { hypopharynx }\end{array}$ & $\begin{array}{l}\text { covered with } \\
\text { stout black setae }\end{array}$ & $\begin{array}{l}\text { covered with } \\
\text { medium setae }\end{array}$ & $\begin{array}{l}\text { covered with } \\
\text { thin setae }\end{array}$ \\
\hline $\begin{array}{l}\text { Dorsal margin of } \\
\text { the femora }\end{array}$ & $\begin{array}{l}\text { a single row of } \\
\text { setae }\end{array}$ & $\begin{array}{l}\text { a double row of } \\
\text { setae }\end{array}$ & $\begin{array}{l}\text { a single row of } \\
\text { setae }\end{array}$ \\
\hline $\begin{array}{l}\text { Dorsal margin of } \\
\text { the tibiae and } \\
\text { tarsi }\end{array}$ & short setae & long setae & no setae \\
\hline Tarsal claws & $\begin{array}{l}2 \text { equal rows of } 6- \\
8 \text { teeth }\end{array}$ & $\begin{array}{l}2 \text { unequal rows } \\
\text { of teeth (3-4 and } \\
4-6)\end{array}$ & $\begin{array}{l}2 \text { unequal rows } \\
\text { of teeth }(4-5 \text { and } \\
6-7)\end{array}$ \\
\hline $\begin{array}{l}\text { Abdomen } \\
\text { coloration } \\
\text { (last larval stage) }\end{array}$ & very contrasted & very contrasted & mostly uniform \\
\hline $\begin{array}{l}\text { Spines of the } \\
\text { paraproct }\end{array}$ & $\begin{array}{l}\text { short, irregular } \\
\text { and stout }\end{array}$ & $\begin{array}{l}\text { short, irregular } \\
\text { and stout }\end{array}$ & long and thin \\
\hline Sterna 1-5 & $\begin{array}{l}\text { covered with } \\
\text { stout setae, no } \\
\text { scale bases }\end{array}$ & $\begin{array}{l}\text { no setae } \\
\text { no scale bases }\end{array}$ & $\begin{array}{l}\text { few thin setae } \\
\text { and scale bases }\end{array}$ \\
\hline
\end{tabular}

Cerci and median caudal filament light brown, each segment with a row of triangular, blunt teeth.

\section{Male imago}

Maximal length: Body $10 \mathrm{~mm}$. Cerci unknown. Forewing $9.2 \mathrm{~mm}$. Hindwing $1.3 \mathrm{~mm}$.

Head. Light brown without marking, only the margins of some sclerites darker. Carena well-developed between the antennae (Fig. 17). Turbinated eyes (Fig. 16) yellowish brown except the basis dark brown. Antennae light brown; scapus with a distal margin U-shaped.
Thorax. Light brown, with only a symmetrical middle brown marking. Forewing (Fig. 13) hyaline, with only one intercalary vein relatively long between the longitudinal veins except between subcostal and first radial veins; pterostigma with 5 to 8 vertical crossveins that generally do not reach the subcostal vein. Hindwing (Fig. 14) hyaline; 3 longitudinal veins wellmarked, first and second joined at the basis, 2 incomplete veins between the second and the third; 2 clearly distinct spurs on the costal margin. Legs light brown; length of the foreleg: femora $1.75 \mathrm{~mm}$, tibiae $2.9 \mathrm{~mm}$, tarsi $2.5 \mathrm{~mm}$. 


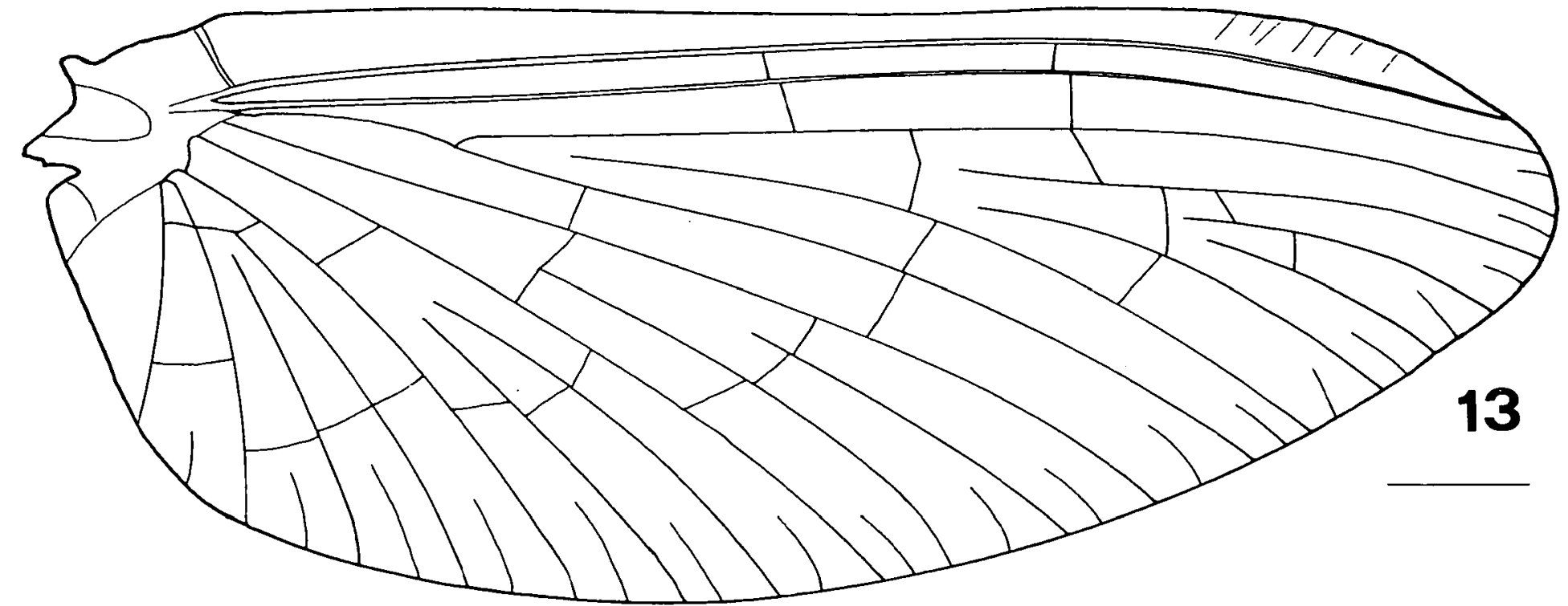

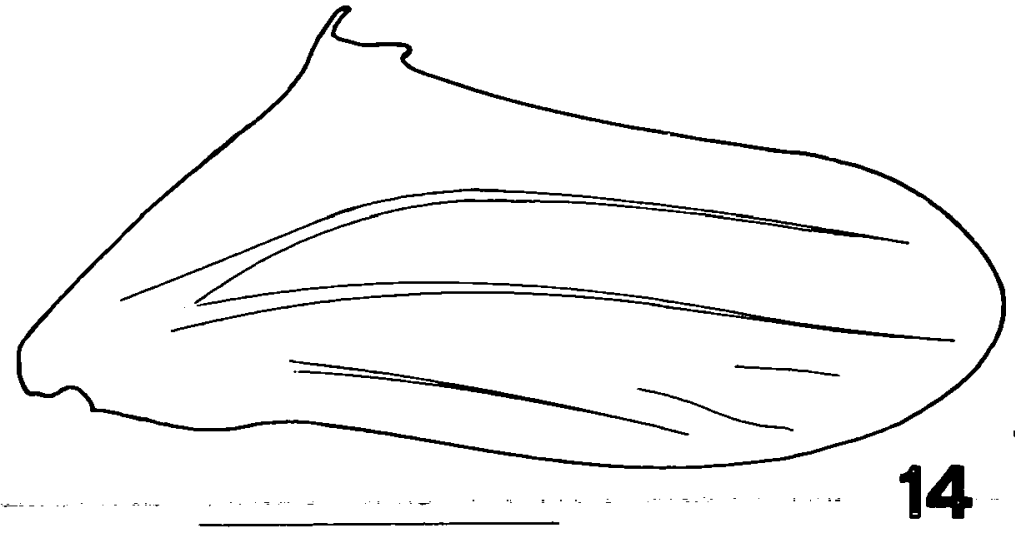

14

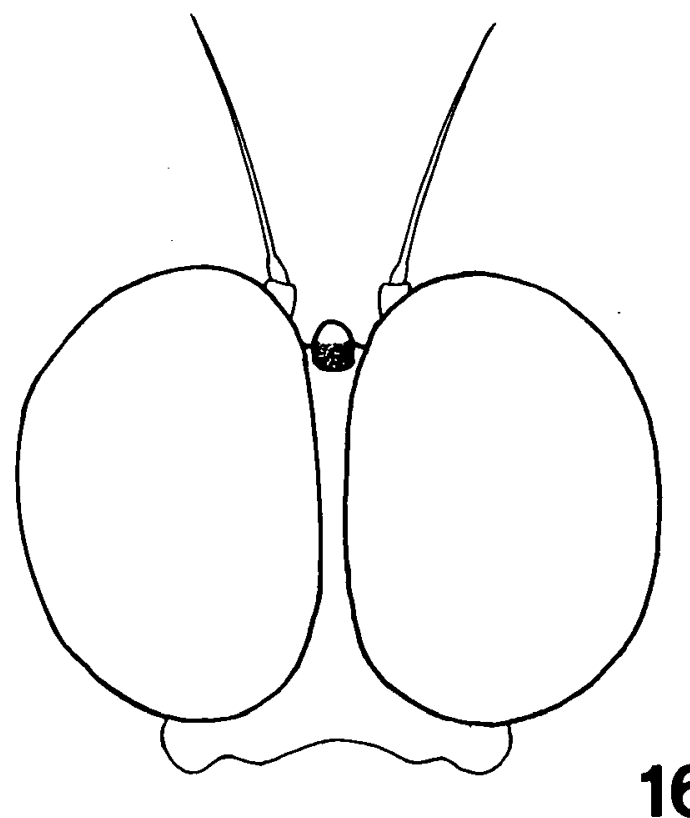

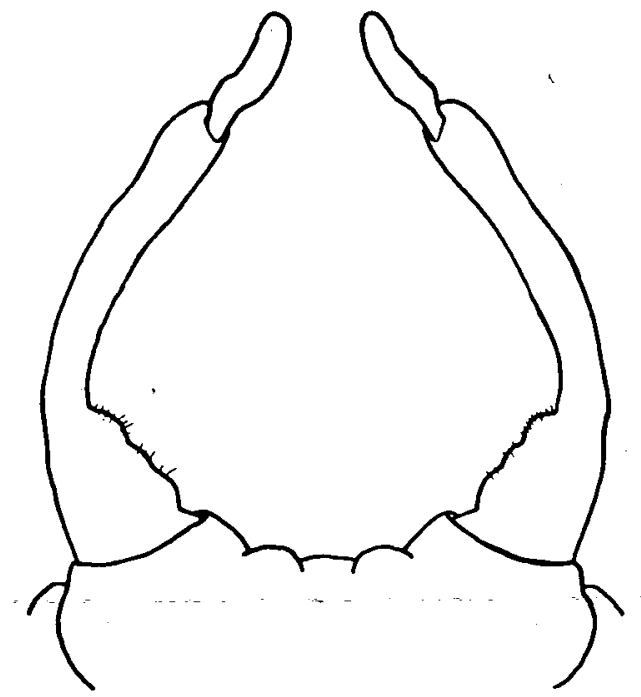

15

Figs 13 to 17 . Imaginal structures of $H$. elouardi $: 13:$ forewing. $14:$ hindwing. $15:$ genitalia. $16:$ head (dorsal view). $17:$ head (lateral view) Scale : $0.5 \mathrm{~mm}$, except fig. $13(1 \mathrm{~mm})$.

Figs 13 à 17 . Structures imaginales de $H$. elouardi : $13:$ aile antérieure. 14 : aile postérieure. $15:$ génitalia. $16:$ tête (vue dorsale). $17:$ tête (vue latérale).

Echelle : $0.5 \mathrm{~mm}$, sauf fig. $13(1 \mathrm{~mm})$. 
Abdomen. Coloration of the terga: first segment middle brown, segment 2 to 6 with a brown marking covering the distal part of terga, segment 7 to 9 brown.

Genitalia (Fig. 15) with 3-segmented gonopods, totally streaked, the limit between the first and the second barely visible. Basal segment weakly developed. First segment stout, wide becoming narrow suddenly toward the apex, inner margin covered with thin setae; second segment elongated, narrow especially at the basis; third segment elongated, four times longer than wide.

\section{Female imago}

Maximal length: Body $11.2 \mathrm{~mm}$. Cerci $23.8 \mathrm{~mm}$. Forewing $10.5 \mathrm{~mm}$. Hindwing $1.5 \mathrm{~mm}$

Head. Same as male one, except the turbinate eyes.

Thorax. Same coloration and marking as the male. Forewing and hindwing similar to those of the male, except the size. Legs light brown; length of the foreleg: femora $2.0 \mathrm{~mm}$, tibiae $1.95 \mathrm{~mm}$, tarsi $0.75 \mathrm{~mm}$.

Abdomen. Coloration of the terga uniformly light brown. Sterna yellowish brown.

Cerci yellowish brown, black at the apex of each segment; surface covered with setae.

Subgenital area with distal part of the sternite 7 with few thin, short setae and sternite 8 depressed in the proximal part with few thin, short setae.

\section{Material examined:}

Holotype: one male imago with corresponding larval exuviae ( $\left.{ }^{\circ} 209 f\right), 16.4 .1994$, Madagascar, Namorona basin; $\mathrm{Na}$ morona river; locality Ranomafana; long. $47^{\circ} 27^{\prime} 18^{\prime \prime} \mathrm{E}$; lat. $21^{\circ} 15^{\prime} 37^{\prime \prime} \mathrm{S}$; altitude $725 \mathrm{~m}$.

Paratype: one female imago with corresponding larval exuviae $\left(\mathrm{n}^{\circ} 209 \mathrm{a}\right)$, same data as the holotype.

Additional material: one male imago $\left(\mathrm{n}^{\circ} 214 \mathrm{a}\right)$; 17.4.1994; Madagascar; Namorona basin; Ambatandrano river; loc. Ambatandrano; long. $47^{\circ} 26^{\prime} 32^{\prime \prime}$ E; lat. $21^{\circ} 14^{\prime} 45^{\prime \prime}$ ' S; altitude $775 \mathrm{~m}$. One male larva $\left(\mathrm{n}^{\circ} 665 \mathrm{a}\right)$, one female larva ( $\left.{ }^{\circ} 665 \mathrm{~b}\right)$ and 2 larvae; 21.11.1996; Madagascar; Betsiboka basin; Lakazana river; loc. Ankondondona; long. $47^{\circ} 45^{\prime} 47^{\prime \prime}$ E; lat. $18^{\circ} 04^{\prime} 57^{\prime \prime}$ S; altitude $1070 \mathrm{~m}$.

\section{Herbrossus christinae Gattolliat \& Sar- tori sp. $\mathbf{n}$.}

\section{Larva}

Maximal length (full grown specimen): Body 10,7 mm. Cerci broken. Terminal filament $4.1 \mathrm{~mm}$.
Head. Coloration middle brown without vermiform markings on vertex and frons.

Antennae pale yellowish brown, slightly less than 3.0 times width of the head capsule; scapus wider than long; pedicellus subcylindrical, longer than wide, distal margin U-shaped.

Eyes black, turbinated eyes dark brown; ocelli grey.

Labrum (Fig. 18) with a deep and broad U-shaped anteromedial emargination, narrower at the basis, dorsally covered with numerous setae, longer in the distal part; margin laterally and apically with setae becoming feathered toward the apex; ventrally with a row of very small setae subparallel to the lateral margin.

Hypopharynx as in figure 19; lingua covered with thin setae but without bristle tuft at the apex.

Right mandible (Fig. 20) with a conspicuous convex angulation on the extern margin; incisors fused to a group of 6 to 7 sharp teeth; prostheca quite reduced; 2 distinct tufts of setae between prostheca and mola; mola unusually reduced, 5 long setae under the mola; tuft of long setae at the apex of the mola with a patch of small pointed teeth just around; basal half with few short setae dorsally, stouter nearby the extern margin.

Left mandible (Fig. 21) with a well-marked convex angulation on the extern margin; incisors fused to a group of 6 sharp teeth; prostheca well-developed, with 5 teeth together with a comb-shaped structure at the apex; tuft of setae between prostheca and mola absent; mola surmounted by a stout triangular appendice; mola reduced, formed with numerous small teeth; tuft of long setae at the apex of the mola; basal half with few short setae dorsally, stouter nearby the extern margin.

Maxillae (Fig. 22) with 4 teeth, row of medium single setae ending with a tuft of setae twice as long as the others; in the middle of the range, 2 pectined spinelike setae; a row of 4 setae at the basis of the galea; 1 single setae perpendicularly to the margin of the galea; palp 2-segmented slightly longer than galealacinia, first segment subequal to the second; outer margin of the first segment and apex of the second with thin setae.

Labium (Fig. 23) with glossae shorter than the paraglossae; inner margin of the glossae with stout setae apically, the 3 most apical slightly pectinated, distal half of the outer margin with few stout setae, few setae randomly distributed on the ventral side; paraglossae stout, apically rounded, with 3 rows of simple pectinated setae and 2 or 3 independent simple setae.

Labial palp 3-segmented; first segment stout, as long as the second and third combined, covered with micropores except near the margins, inner margin with thin 

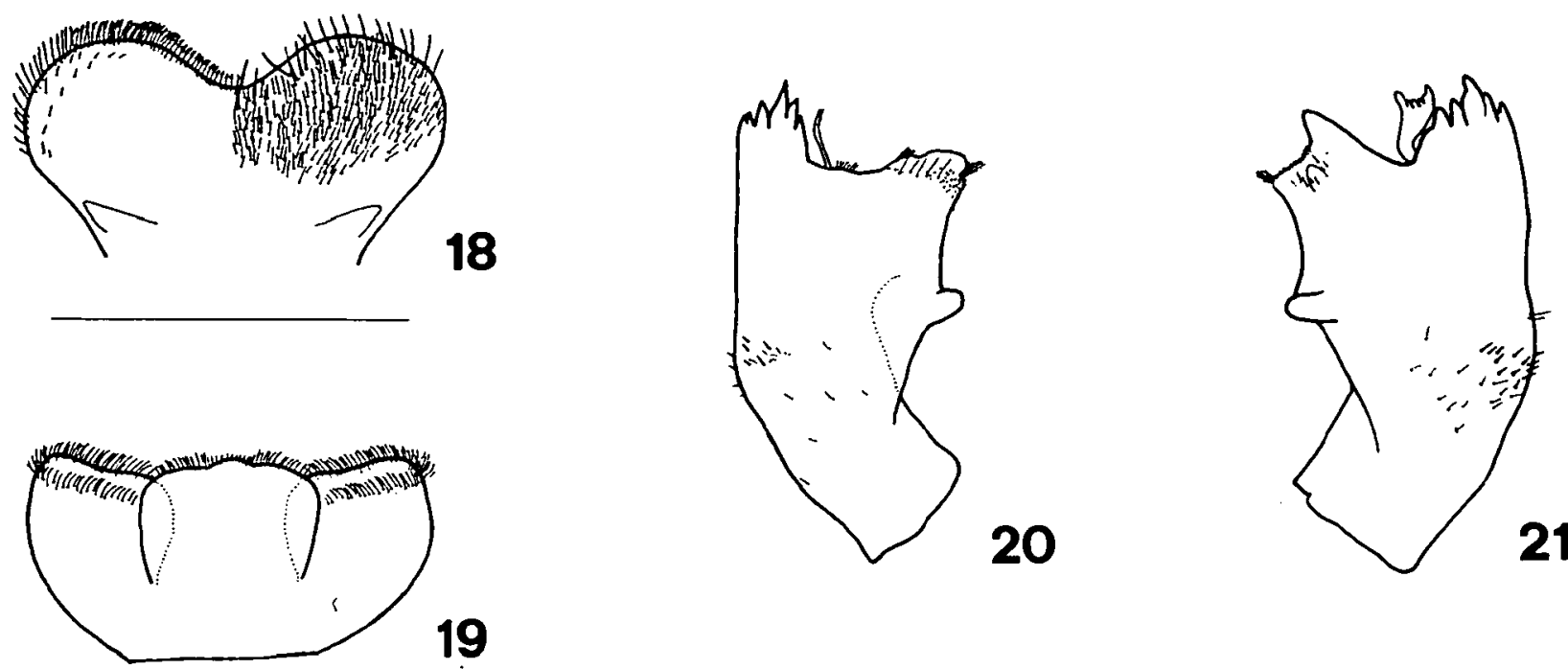

19
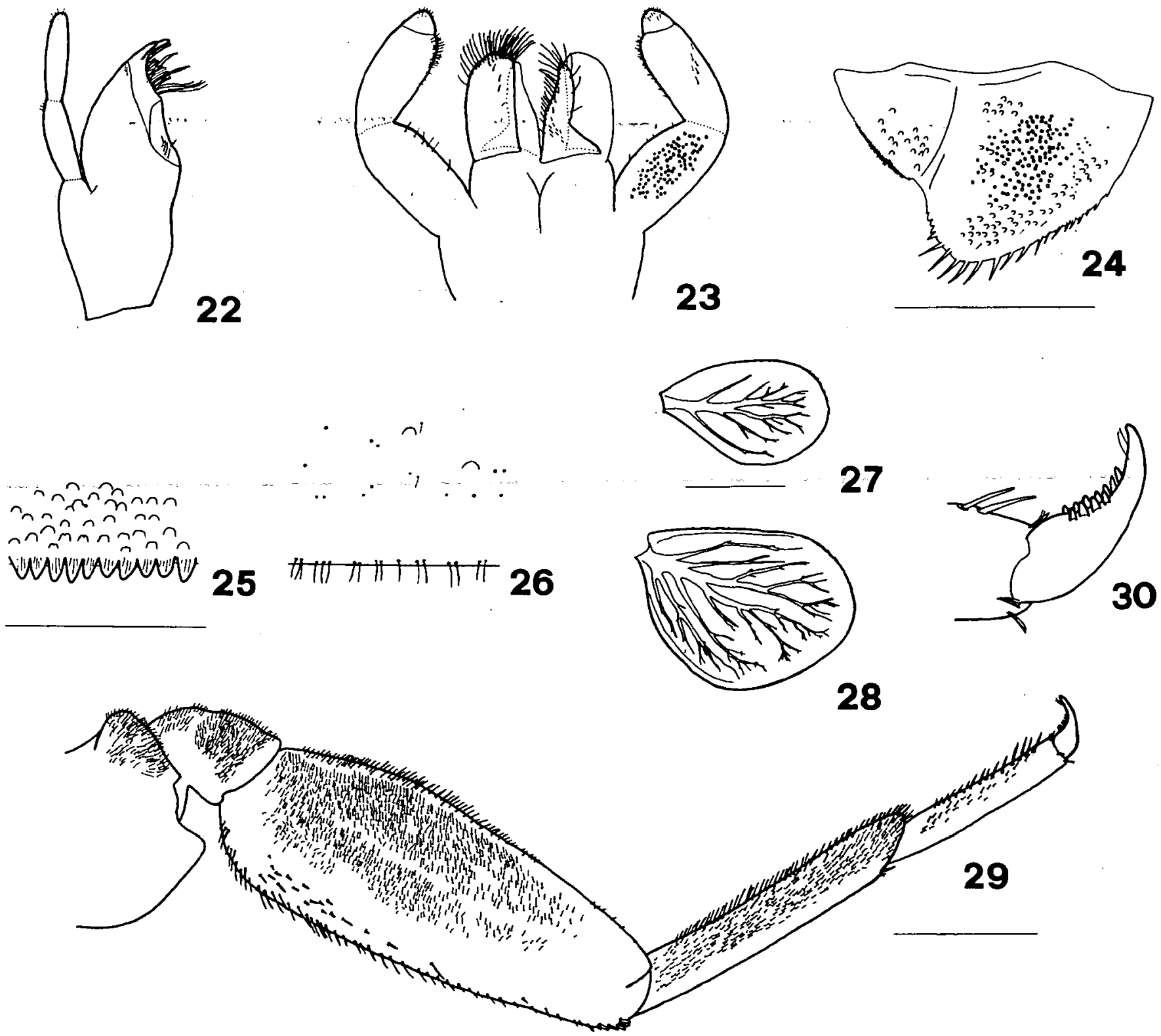

Figs 18 to 30. Larval structures of $H$. christinae : $18:$ labrum. $19:$ hypopharynx. $20:$ right mandible. $21:$ left mandible. $22:$ right maxilla. 23 : labium (left : ventral; right : dorsal). $24:$ paraproct. $25:$ detail of tergum. $26:$ detail of sternite. $27:$ first gill. $28:$ third gill. $29:$ left foreleg. $30:$ tarsal claw.

Scale : $0.5 \mathrm{~mm}$, except fig. 25 and $26(0.125 \mathrm{~mm})$, figs 24,27 and $28(0.25 \mathrm{~mm})$. Same scale for figures 18-23.

Figs 18 à 30 . Structures larvaires de $H$. christinae : $18:$ labre. $19:$ hypopharynx. $20:$ mandibule droite. $21:$ mandible gauche. $22:$ maxille droite. $23:$ labium (gauche : ventral; droite : dorsal). $24:$ paraprocte. $25:$ détail du tergite. $26:$ détail du sternite. $27:$ première branchie. $28:$ troisième branchie. 29 : patte antérieure gauche. 30 : griffe tarsale.

Echelle : $0.5 \mathrm{~mm}$, sauf fig. 25 et $26(0.125 \mathrm{~mm})$, figs 24,27 et $28(0.25 \mathrm{~mm})$. Mêmes échelles pour les figures 18 à 23 . 
setae; second segment slightly produced apicomedially, patch of 5 to 7 setae near the outer margin, inner margin covered with thin setae in the distal part; third segment subconical, covered with setae.

Thorax. Coloration yellowish brown with medium brown slightly visible marking. Forewing pad yellow brown, major veins slightly marked with brown lines; hindwing pad present.

Forelegs (Fig. 29) with coxa covered with numerous relatively long setae.

Femora with dorsally a single row of long setae, ending with a patch of stout setae; sparse stout setae subparallel to the margin especially on the proximal region; numerous apically long and blunt setae on the ventral margin; posterior face covered with numerous thin setae.

Tibiae without any seta-dorsally; numerous stout, apically pointed setae on the ventral margin and the posterior face.

Tarsi without any seta dorsally; a row of stout, apically pointed setae becoming longer toward the apex on the ventral margin; posterior face with several smaller pointed setae; 2 tufts of setae at the apex dorsally and ventrally; tarsal claws (Fig. 30) stout with 2 unequal rows of teeth, 4 to 5 for the posterior row and 6 to 7 for the anterior; claw with a subapical pair of long, thin, simple setae.

Second and third legs similar to foreleg, but with the setae on the ventral margin less developed.

Abdomen. Coloration yellow to middle brown uniform for all the terga.

Terga (Fig. 25) with abundant scale bases; posterior marginal spines relatively regular, triangular, longer than wide; marks of muscular attachments well-developed; very scarce setae between the spines.

Sterna (Fig. 26) yellow, with few thin setae and scale bases, marks of muscular attachments well-developed.

Gills on abdominal segments 1 to 7 , well-tracheated, serrated at the apex; gill 1 smaller than the others, shape as in figure 27; Gills 2 to 7 identical in shape (Fig. 28), except 6 and especially 7 smaller.

Paraproct (Fig. 24) with about 20 spines, the 10 apico-lateral very long and thin; surface covered with micropores and scarce scale bases; few thin setae randomly distributed near the margin; postero-lateral extension with numerous spines along the margin, surface with more than 15 scale bases.
Cerci and medial caudal filament light brown, each segment with a row of triangular, blunt teeth at the apex.

\section{Male and female imagos}

unknown

\section{Material examined}

Holotype: one male larva ( ${ }^{\circ}$ 693a); 22.4.1997; Madagascar; Rianila basin; unnamed river; loc. road to Lakato; long. $48^{\circ} 21^{\prime} 48^{\prime \prime} \mathrm{E}$; lat. $19^{\circ} 02^{\prime} 40^{\prime \prime} \mathrm{S}$; altitude $1050 \mathrm{~m}$.

Paratypes: one young larva same data as holotype. One female larva ( ${ }^{\circ}$ 692a); 22.4.1997; Madagascar; Rianila basin; unnamed river; loc. road to Lakato; long. $48^{\circ} 21^{\prime} 51^{\prime \prime} \mathrm{E}$; lat. $19^{\circ} 02^{\prime} 22^{\prime \prime} \mathrm{S}$; altitude $1050 \mathrm{~m}$. One female larva $\left(\mathrm{n}^{\circ} 657 \mathrm{a}\right)$; 26.11.1996; Madagascar; Rianila; unnamed river; loc. road to Lakato; long. $48^{\circ} 21^{\prime} 50^{\prime \prime} \mathrm{E}$; lat. $19^{\circ} 03^{\prime} 30^{\prime \prime} \mathrm{S}$; altitude $1075 \mathrm{~m}$. One female larva $\left(\mathrm{n}^{\circ} 667 \mathrm{a}\right)$, one male larva $\left(\mathrm{n}^{\circ} 667 \mathrm{~b}\right)$ and 4 larvae; 27.11.1996; Madagascar; Rianila basin; Amboasary river; loc. Andasibe (Périnet, Mantadia reserve); long. 48 $25^{\prime} 26^{\prime \prime} \mathrm{E}$; lat. $19^{\circ} 03^{\prime} 30^{\prime \prime} \mathrm{S}$; altitude $950 \mathrm{~m}$.

\section{Herbrossus edmundsorum McCafferty \& Lugo-Ortiz, 1998}

The study of our material allows us to precise some features.

Larva

Head: Lingua of the hypopharynx with brown, stout setae at the apex.

Extern margin of the right and left mandibles with no or slighty marked convex angulation.

Thorax: Similar to H. elouardi, except: Femora with a single row of long setae. Dorsal margin of the tibia with short, pointed setae. Dorsal margin of the tarsi with short, pointed setae.Tarsal claws with 2 equal rows of 6-8 teeth.

Abdomen: Similar to H. elouardi, except: Sterna 1 to 5 covered with stout setae.

\section{Male imago}

unknown

\section{Female imago}

Maximal length: Body $8.5 \mathrm{~mm}$. Cerci more than $13.5 \mathrm{~mm}$ (broken). Forewing $8.5 \mathrm{~mm}$. Hindwing 1.2 $\mathrm{mm}$.

Head. Light brown without marking, only the margins of some sclerites darker. Carena well-developed between the antennae. Antennae light brown; scapus with a distal margin U-shaped.

Thorax. Light brown, with only a symmetrical middle brown marking. Forewing hyaline, with only one in- 
tercalary vein relatively long between the longitudinal veins except between subcostal and first radial veins; pterostigma with 8 vertical cross-veins that generally do not reach the subcostal vein. Hindwing hyaline; 3 longitudinal veins well-marked, first and second joined at the basis; generally 2 incomplete veins between the second and the third; 2 clearly distinct spurs. Legs light brown; length of the foreleg, femora: $1.0 \mathrm{~mm}$, tibiae: $1.1 \mathrm{~mm}$, tarsi: $0.9 \mathrm{~mm}$.

Abdomen. Coloration of the terga uniformly light brown. Sterna yellowish brown.

Cerci yellowish brown, black at the apex of each segment; surface covered with setae.

Subgenital area with distal part of the sternite 7 covered with few thin, short setae and distal margin slighty prolongated as an apophysis; sternite 8 depressed in the proximal part with brown, thin and short setae.

\section{Material examined}

One female imago with corresponding larval exuviae $\left(\mathrm{n}^{\circ} 209 \mathrm{~g}\right), 16.4 .1994$, Madagascar; Namorona basin; Namorona river; locality Ranomafana; long. $47^{\circ} 27^{\prime} 18^{\prime \prime} \mathrm{E}$; lat. $21^{\circ} 15^{\prime} 37^{\prime \prime} \mathrm{S}$; altitude $725 \mathrm{~m}$.

One female imago with corresponding larval exuviae (nº41-1); 5.11.1996; same station.

Eight larvae ( $\left.\mathrm{n}^{\circ} 210\right)$; 16.4.1994; Madagascar; Namorona basin; Namorona river; locality Ranomafana; long. $47^{\circ} 27^{\prime} 09^{\prime \prime} \mathrm{E}$; lat. $21^{\circ} 15^{\prime} 30^{\prime \prime} \mathrm{S}$; altitude $725 \mathrm{~m}$.

Three larvae $\left(n^{\circ} 644\right) ; 8.11 .1996$; Madagascar; Namorona basin; Namorona river; locality Ranomafana; long. $47^{\circ} 27^{\prime} 28^{\prime \prime} \gg \mathrm{E}$; lat. $21^{\circ} 15^{\prime} 40^{\prime \prime} \mathrm{S}$; altitude $725 \mathrm{~m}$.

One male larva $\left(n^{\circ} 44 b\right)$ and one female larva $\left(n^{\circ} 44 a\right)$; 17.4.1991; Madagascar; Betsiboka basin; Andranofeno ri-

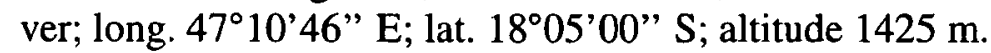

Two male larvae $\left(\mathrm{n}^{\circ} 45 \mathrm{~b}\right.$ and $\left.\mathrm{c}\right)$ and larvae; 17.4 .1991 ; Madagascar; Betsiboka basin; Manankazo river; loc. Mananka-

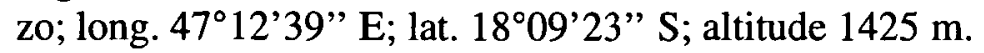

One larva $\left(n^{\circ} 163 \mathrm{a}\right) ; 16.11 .1993$; Madagascar; Manampatrana basin; Iantara river; loc. Andringitra; long.

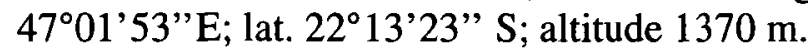

One larva (n447a), 18.6.1995; Madagascar; Manampatrana basin; Mahazoala river; loc. unnamed; long. $47^{\circ} 17^{\prime} 49$ » E; lat. $22^{\circ} 40^{\prime} 55$ » $\mathrm{S}$; altitude $170 \mathrm{~m}$.

Two larvae ( ${ }^{\circ} 243 \mathrm{c}$ and 243d); 6.5.1994; Madagascar; Mangoro basin; Mangoro river; loc. bridge over the Mangoro; long. $48^{\circ} 06^{\prime} 32^{\prime \prime} \mathrm{E}$; lat. $18^{\circ} 52^{\prime} 32^{\prime \prime} \mathrm{S}$; altitude $840 \mathrm{~m}$.

One female larva $\left(\mathrm{n}^{\circ} 284 \mathrm{a}\right)$ and three larvae; 11.3.1995; Madagascar; Mangoro basin; Ankeniheny river; loc. Manjakatompo Ankaratra reserve; long. 47 19'53" E; lat. $18^{\circ} 52^{\prime} 32^{\prime \prime} \mathrm{S}$; altitude $1610 \mathrm{~m}$.
One larva ( $\left.{ }^{\circ} 298\right)$; 21.3.1995; Madagascar; Rianila basin; unnamed river; loc. road to Lakato; long. $48^{\circ} 21^{\prime} 38^{\prime \prime} \mathrm{E}$; lat. $19^{\circ} 03^{\prime} 07^{\prime \prime} \mathrm{S}$; altitude $1050 \mathrm{~m}$

One male larva ( $\left.{ }^{\circ} 693 \mathrm{~b}\right)$; 22.4.1997; Madagascar; Rianila basin; unnamed river; loc. road to Lakato; long. $48^{\circ} 21^{\prime} 48^{\prime \prime}$ E ; lat. 1902'40" S; altitude $1050 \mathrm{~m}$.

Five larvae $\left(n^{\circ} 457\right)$; 20.6.1995; Madagascar; Matitanana basin; Matitanana river; loc. aval of Ankarimbelo; long. $47^{\circ} 20^{\prime} 14^{\prime \prime} \mathrm{E}$; lat. $22^{\circ} 08^{\prime} 00^{\prime \prime} \mathrm{S}$; altitude $460 \mathrm{~m}$.

14 larvae $\left(n^{\circ} 585\right) ; 13.4 .1996$; Madagascar; Tsiribihina basin; unnamed river; long. $46^{\circ} 59^{\prime} 47^{\prime \prime} \mathrm{E}$; lat. $19^{\circ} 26^{\prime} 57^{\prime \prime} \mathrm{S}$; altitude $1890 \mathrm{~m}$.

One female larva $\left(n^{\circ} 598 a\right)$, two male larvae $\left(n^{\circ} 598 b\right.$ and 598c) and five larvae ( $\left.\mathrm{n}^{\circ} 598\right)$; 23.5.1996; Madagascar; Tsiribihina basin; Ivato river; loc. Ivato; long. $47^{\circ} 10^{\prime} 30^{\prime \prime} \mathrm{E}$; lat. $20^{\circ} 39^{\prime} 40^{\prime \prime} \mathrm{S}$; altitude $1500 \mathrm{~m}$.

One larva $\left(n^{\circ} 339-30\right) ; 2.6 .1994$; Madagascar; Mandrare basin; Mananara river; loc. Hazototsy; long. $46^{\circ} 35^{\prime} 46^{\prime \prime} \mathrm{E}$; lat. $24^{\circ} 48^{\prime} 57^{\prime \prime} \mathrm{S}$; altitude $100 \mathrm{~m}$.

One female larva ( $\left.{ }^{\circ} 340-8\right)$; 2.6.1994; Madagascar; Mandrare basin; Marotoko river; loc. Hazototsy; long. $46^{\circ} 35^{\prime} 46^{\prime \prime}$ E; lat. $24^{\circ} 48^{\prime} 47^{\prime \prime} \mathrm{s}$; altitude $100 \mathrm{~m}$.

Two larvae (n ${ }^{\circ} 343-11$ and $\left.n^{\circ} 343-13\right) ; 5.6 .1994$; Madagascar; Mandrare basin; Manambolo river; loc. $7 \mathrm{~km}$ from Berohanga; long. $46^{\circ} 35^{\prime} 11^{\prime \prime} \mathrm{E}$; lat. $24^{\circ} 35^{\prime} 07^{\prime \prime} \mathrm{S}$; altitude $440 \mathrm{~m}$.

\section{Affinities}

On the basis of this study, the genus Herbrossus appears to be very homogenous. Lugo-Ortiz \& MčCafferty (1998) put forward the U-shaped anteromedial emargination of the labrum (Figs 1, 18) as a generic apomorphy. We can also consider the stout setae on the foreleg (Figs 11, 29), as well as the two spurs of the hindwing (Fig. 14) and the longitudinal veins of the hindwing as apomorphic characters which distinguish it from other related genera such as Barnumus, Nesoptiloides, Centroptiloides and Edmulmeatus. The forewing (Fig. 13), with a single intercalary veins between the longitudinal vein, is a plesiomorphic character common to all the species of the Centroptiloides complex (Lugo-Ortiz \& McCafferty 1998).

The three species can be easily determined by the characters stated in table 1 . The most reliable features to distinguish $H$. elouardi from other species is the double row of setae on the dorsal margin of the femora (Fig. 11) and the presence of long setae on the dorsal margins of the tarsi and tibiae. The long and thin spines on the margin of the paraproct (Fig. 24), the mandibles (Fig. 20,21) with a well-marked convex angulation on the extern margin and the reduction of the mandibular mola are apomorphies of $H$. christinae. H. edmundsorum presents the higher number of plesiomorphic cha- 
racters, the only apomorphy seems to be the presence of stout setae on sterna 1 to 5 .

\section{Distribution}

H. edmundsorum is widely distributed throughout Madagascar. It has been found in all the main investigated basins of the Eastern coast. On the Western coast, it is present only in two basins. This distribution could be explained by the proximity of these basins or by a species presence prior to the orogenesis.

H. elouardi is present only in two basins of the Eastern and the Western coast. In one station, it is sympatric with $H$. edmunsorum. This discontinuous distribution is rather unusual, but a lack of information could explain it to some extent.

$H$. christinae is located in only a few places of a single basin. This species is also sympatric with $H$. edmunsorum.

\section{Biology}

These three species have been caught mainly in medium rivers ( 5 to $30 \mathrm{~m}$ broad), with little depth ( 0.1 to $0.5 \mathrm{~m}$ ) at altitudes between 700 and $1500 \mathrm{~m}$. There was no habitat differences between the three species.

The simultaneous presence of larvae of different size classes suggests the existence of several cohorts throughout the year. The specific characters, such as the sha- pe of the labrum and the setae on the dorsal margin of the legs are already visible at earlier stages.

The evolution of the mandibles and the forelegs of $H$. christinae suggests a feeding behaviour different from the two others. The analysis of the gut content established that $H$. christinae is a pure carnivorous species at least at the old stages, feeding mostly on the Baetidae (Xyrodromeus spp., Afroptilum spp.). On the contrary, H. elouardi and H. edmundsorum appear to be collector-gatherers, feeding mainly on decaing material. At the last larval stage, the behaviour changes abruptely, they become strictly carnivorous, feeding exclusively on invertebrates, mostly on Baetidae ( $\mathrm{Di}$ centroptilum spp., Afroptilum spp.).

\section{Acknowledgements}

We thank the whole team of the Laboratoire de Recherche sur les Systèmes Aquatiques et leur Environnement (LRSAE) and especially its director Dr. J.-M. Elouard, for a logistical assistance, great help during field work and laboratory facilities during our stay in Madagascar. We are also deeply indebted to them for donation of specimens. We also want to thank Dr. W.P. McCafferty and C.R. Lugo-Ortiz, Purdue University, West Lafayette, for constructive discussions on Malagasy Baetidae.

\section{Reference}

Lugo-Ortiz C.R. \& McCafferty W.P. 1998. - The Centroptiloides complex of afrotropical small minnow mayfly (Ephemeroptera: Baetidae). An. Ent. Soc. Am., 91 : 1-26. 